\title{
Persistence in milk, fat and protein production of primiparous Holstein cows by random regression models
}

\author{
Igor de Oliveira Biassus ${ }^{1}$, Jaime Araújo Cobuci $^{1}$, Claudio Napolis Costa ${ }^{2}$, Paulo Roberto \\ Nogara Rorato ${ }^{3}$, José Braccini Neto ${ }^{1}$, Leandro Lunardini Cardoso ${ }^{1}$
}

\footnotetext{
1 UFRGS, Porto Alegre, RS

2 Embrapa Gado de Leite, Juiz de Fora, MG

3 UFSM, Santa Maria, RS.
}

\begin{abstract}
Total numbers of 56,508, 35,091 and 8,326 records of milk, fat, and protein test-day yields, respectively, were used to estimate genetic parameters for six persistency measures on milk, fat and protein productions of Holstein cows reared in Minas Gerais state. Covariance components for additive genetic effects and permanent environmental effects were estimated by REML in random regression models using Legendre polynomials from the third to the sixth order. Overall, models with the highest orders of Legendre polynomials showed the best quality of adjustments of these productive records. Heritability estimates obtained by the models for persistence in milk, fat, and protein yields ranged from 0.04 to 0.32 , from 0.00 to 0.23 , and from 0.00 to 0.27 , respectively. Values of genetic correlation estimates between persistence and total 305-day milk, fat, and protein yields ranged from -0.38 to 0.54 , from -0.39 to 0.97 , and from -0.78 to 0.67 , respectively. Persistence measurement proposed by Jakobsen $\left(\mathrm{PS}_{2}\right)$ is preferential for using in further genetic evaluations for persistence in milk, fat and protein yields of Holstein cows in Minas Gerais state.
\end{abstract}

Key Words: genetic correlation, heritability, Legendre polynomials, random regression model, selection

\section{Persistência na produção de leite, de gordura e de proteína de vacas primíparas da raça Holandesa via modelos de regressão aleatória}

RESUMO - Os totais de 56.508, 35.091 e 8.326 registros, respectivamente, de produção de leite, de gordura e de proteína no dia do controle foram usados para estimar parâmetros genéticos para seis medidas de persistência na produção de leite, de gordura e de proteína de vacas da raça Holandesa criadas em rebanhos do Estado de Minas Gerais. Os componentes de covariância para os efeitos genético aditivo e de ambiente permanente foram estimados via REML por modelos de regressão aleatória com polinômios de Legendre de ordens 3 a 6. Em geral, os modelos com as mais altas ordens dos polinômios de Legendre apresentaram a melhor qualidade no ajuste desses registros produtivos. As estimativas de herdabilidade obtidas pelos modelos para as persistências nas produções de leite, de gordura e de proteína variaram, respectivamente, de 0,04 a 0,$32 ; 0,00$ a 0,23 ; e 0,00 a 0,27 . Os valores das estimativas de correlação genética entre persistência e produções de leite, de gordura e de proteína, em 305 dias, variaram de $-0,38$ a 0,54 ; $-0,39$ a 0,97; e $-0,78$ a 0,67, respectivamente. A medida de persistência proposta por Jakobsen $\left(\mathrm{PS}_{2}\right.$ ) é preferencial para uso em futuras avaliações genéticas para persistências nas produções de leite, de gordura e de proteína de animais da raça Holandesa no Estado de Minas Gerais.

Palavras-chave: correlação genética, herdabilidade, modelo de regressão aleatória, polinômio de Legendre, seleção

\section{Introduction}

Lactation persistence can be defined as the ability of the cow to maintain milk yield (milk, fat, and protein) after achieving the maximum milk production (Cobuci et al., 2003). This trait is directly related to the economical aspects of milk yield as it may allow reduction of milk production costs (Tekerli et al., 2000) by decreasing both feeding costs and those costs related to health and reproduction of the cows.
There are some indications of genetic differences in milk yield persistence among cows (Cobuci et al., 2004; Dorneles et al., 2009), and therefore, selection for this trait may be advantageous, since persistence is the main component of the lactation curve of dairy cattle (Wood, 1967). Despite the demonstrated advantages of selection for milk production, there are few studies evaluating the genetic variability of cows in milk, fat or protein production persistence, particularly in tropical climates. 
Considered as an excellent procedure to evaluate milk production persistence (Lin \& Togashi, 2002), random regression models have been the most commonly methods used in studies involving test-day production in dairy cattle. The use of such models requires the selection of a mathematical function to describe the fixed and the random effects that influence productive traits, and among these functions, Legendre orthogonal polynomials are usually preferred (Liu et al., 2006).

Due to lack of studies on lactation persistence and the importance of this trait, this study aimed at estimating genetic differences among six measures of the persistence of milk, fat, and protein production of primiparous Holstein cows, using random regression models. Legendre polynomials from the third to the sixth order were applied to try to identify measures and models suitable to be applied in future genetic evaluations for these traits.

\section{Material and Methods}

The records of test-day production used in this study were provided by Serviço de Controle Leiteiro e Genealógico da Associação dos Criadores de Gado Holandês de Minas Gerais (ACGH-MG). The initial data file contained 199,248 production records collected from 1989 to 2008 distributed as it follows: 197,861 milk production records of 25,285 cows, 158,261 fat production records of 24,568 cows, and 82,389 protein production records of 16,256 cows.

Records of cows with fewer than 20 and more than 48 months of age at parturition were eliminated, as well as of those with daily milk, fat, or protein production lower than $10.6 \mathrm{~kg}, 295 \mathrm{~g}$, and $306 \mathrm{~g}$, and higher than $36.4 \mathrm{~kg}, 1,246 \mathrm{~g}$, and $1,136 \mathrm{~g}$, respectively. Records of daughters of sire with at least two daughters in at least three herds, of contemporary groups with fewer than 4 observations, of cows with fewer than 6 records per lactation, of cows with records collected between day 6 and 305 after calving, and cows of either pure bred or crossbred Holstein remained in the evaluation.
After editing, three new databases, corresponding to milk, fat and protein production records, were defined (Table 1 ).

Four cow age classes at calving (20 to 25, 26 to 27, 28 to 30 , or 31 to 48 months) and four calving seasons (January to March, April to June, July to September, or October to December) were definied. These classes combined yielded 16 classes of cow calving age-season, which were included in the random regression model as fixed effects.

The contemporary groups were defined by grouping the variables herd, year, and month of milk record.

The random regression model used to fit production records was:

$$
\mathrm{y}_{\mathrm{ijk}}=\mathrm{HYM}_{\mathrm{i}}+\sum_{\mathrm{m}=1}^{\mathrm{n}} \beta_{\mathrm{jm}} \mathrm{Z}_{\mathrm{km}}+\sum_{\mathrm{m}=1}^{\mathrm{n}} \mathrm{a}_{\mathrm{km}} \mathrm{Z}_{\mathrm{km}}+\sum_{\mathrm{m}=1}^{\mathrm{n}} \mathrm{p}_{\mathrm{km}} \mathrm{Z}_{\mathrm{km}}+\mathrm{e}_{\mathrm{ijk}},
$$

where $y_{i j k}=$ production $k$ (milk, fat, or protein), on any of lactation day $t$ within the classes $i$ (herd-year-month of test) and $j$ (calving age-season); $H Y M_{i}=$ fixed effect herdyear-month of testing; $\beta_{j m}=$ vector of fixed regression coefficients of test-day production that describes the regression fixed within calving age-season classes, $a_{k m}$ and $p_{k m}=$ vectors of random regression coefficients that describe, respectively, the additive genetic effects and the permanent environmental effects on cow yield $k$; $e_{i j k}=$ random residual effect associated with $y_{i j k} ; Z_{k m}=$ covariate specific vector representing Legendre polynomial, in which $\mathrm{m}=$ the $\mathrm{n}$-th parameter of Legendre polynomials of the $3^{\text {rd }}, 4^{\text {th }}, 5^{\text {th }}$, or $6^{\text {th }}$ orders.

The models were called M3, M4, M5 and M6 when Legendre polynomials of the $3^{\text {rd }}, 4^{\text {th }}, 5^{\text {th }}$, or $6^{\text {th }}$ order were applied for modeling random production curves (genetic and permanent environment effects), as well as for modeling of fixed production curves (average) of cows in different age classes-calving season.

Estimates of the genetic and permanent environment effects for total 305-day production and measures of milk, fat, and protein production persistence were obtained by multiplying covariance matrices and vectors containing covariates specific for each persistence measure and for total 305-day production (Table 2).

Table 1 - Description of the databases

\begin{tabular}{|c|c|c|c|}
\hline & Database 1 & Database 2 & Database 3 \\
\hline Trait & Milk & Fat & Protein \\
\hline Number of records & 56,508 & 35,091 & 8,326 \\
\hline Year of birth & 1993 to 2005 & 1993 to 2005 & 1996 to 2005 \\
\hline Year of calving & 1997 to 2007 & 1997 to 2007 & 1999 to 2007 \\
\hline Number of herds & 211 & 154 & 51 \\
\hline Average daily yield & $23.64 \mathrm{~kg}$ & $754 \mathrm{~g}$ & $725 \mathrm{~g}$ \\
\hline
\end{tabular}


Table 2 - Persistence measures and production in 305 days used in this study

\begin{tabular}{lc}
\hline Measures & \multicolumn{1}{c}{ Authors } \\
\hline$P S_{1}=\left(E B V_{280}-E B V_{60}\right)$ & Jamrozik et al. (1997) \\
$P S_{2}=\left(\sum_{t=106}^{205} E B V_{t}-\sum_{t=6}^{105} E B V_{t}\right)$ & Jakobsen et al. (2002) \\
$P S_{3}=\left(\sum_{t=206}^{305} E B V_{t}-\sum_{t=6}^{105} E B V_{t}\right)$ & Jakobsen et al. (2002) \\
$P S_{4}=\left(\sum_{t=61}^{280} E B V_{t}-E B V_{60}\right)$ & Jamrozik et al. (1997) \\
$P S_{5}=\left(\sum_{t=60}^{279} E B V_{t}-E B V_{280}\right)$ & Jakobsen et al. (2002) \\
$P S_{6}=\left(E B V_{290}-E B V_{90}\right)$ & Cobuci et al. (2004) \\
$P_{305}=\sum_{t=6}^{305} E B V_{t}$ & \\
\hline EBV $=$ genetic value on any day t of the lactation period. \\
PS = persistence measure. \\
$\mathrm{P}_{305}=$ total yield in 305 days.
\end{tabular}

Covariance matrices of random regression coefficients were estimated by the program REMLF90 (Misztal, 2002), which uses the method of restricted maximum likelihood (REML).

The four models were compared according to the quality of fit of the production records of the three traits using the following criteria: the sum of the residual variance in lactation (SRV), value of -2log of maximum function likelihood (ML), Akaike information criterion (AIC) (Akaike, 1973), and the Bayesian information criterion (BIC) (Schwarz, 1978).

\section{Results and Discussion}

Legendre polynomials from the third to the sixth order applied for the models did not provide a definite trend (decrease or increase) in the estimated covariance among the random regression coefficients (Tables 3 to 5). In these models, the additive genetic effects and permanent

Table 3 - Genetic and permanent environmental covariance estimated by random regression and residual variance coefficients obtained by fitting test-day milk production into different models

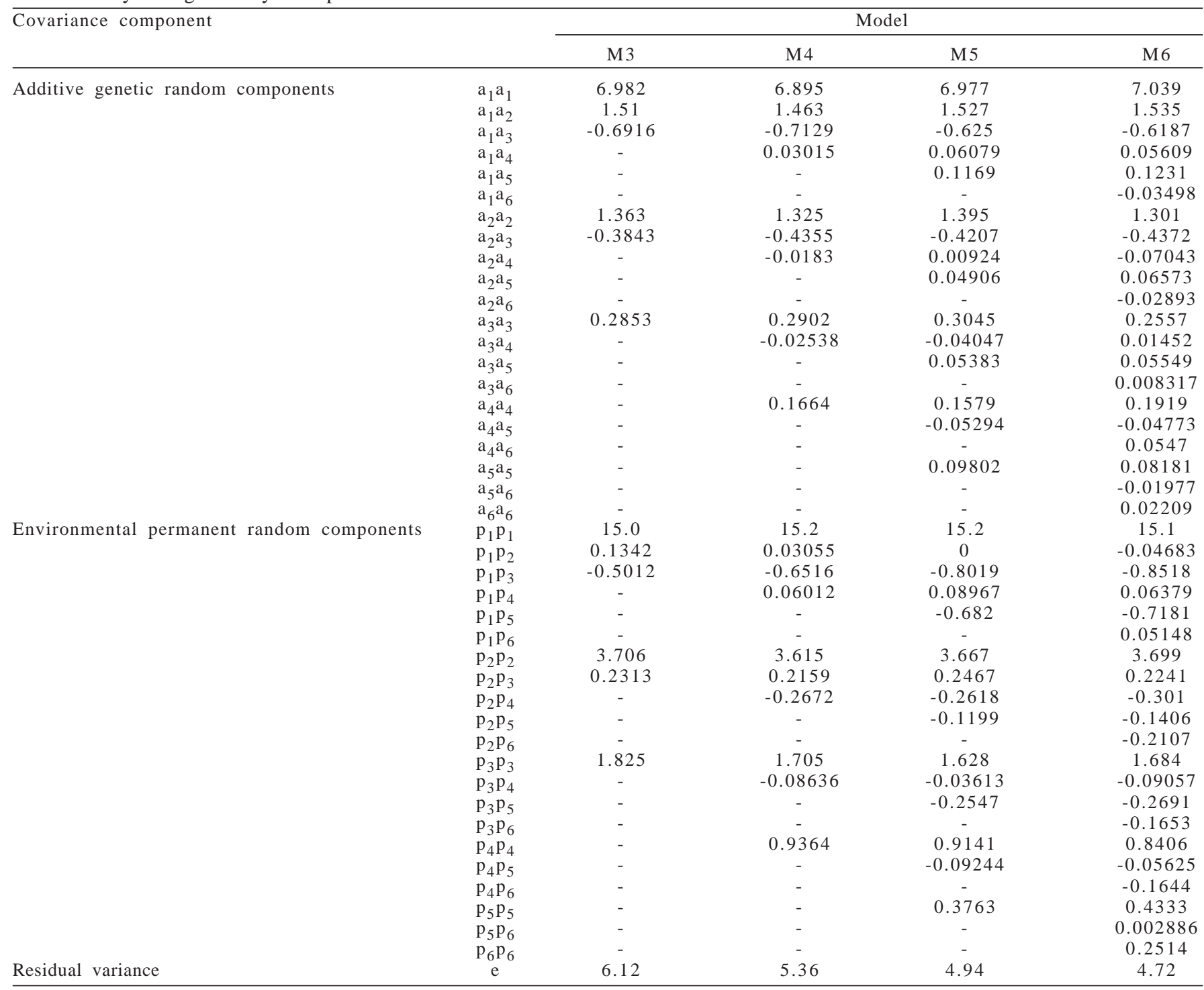


Table 4 - Genetic and permanent environmental covariance estimated by random regression and residual variance coefficients obtained by fitting test-day fat production into different models

\begin{tabular}{|c|c|c|c|c|c|}
\hline \multirow[t]{2}{*}{ Covariance component } & & \multicolumn{4}{|c|}{ Model } \\
\hline & & M3 & M4 & M5 & M6 \\
\hline \multirow[t]{21}{*}{ Additive genetic random components } & $a_{1} a_{1}$ & 7,377 & 6,827 & 7,479 & 7,226 \\
\hline & $a_{1} a_{2}$ & 964.7 & 1,539 & 861.2 & 945.4 \\
\hline & $a_{1} a_{3}$ & -557.3 & -819.4 & -535.7 & -503.6 \\
\hline & $a_{1} a_{4}$ & - & -296.4 & -160.0 & -155.9 \\
\hline & $a_{1} a_{5}$ & - & - & 330.5 & 294.0 \\
\hline & $a_{1} a_{6}$ & - & - & - & -48.48 \\
\hline & $a_{2} a_{2}$ & 953.5 & 382.7 & 803 & 820.3 \\
\hline & $a_{2} a_{3}$ & -162.7 & -178.1 & -239.5 & -208.7 \\
\hline & $\mathrm{a}_{2} \mathrm{a}_{4}$ & - & -79.85 & -211.6 & -247.8 \\
\hline & $a_{2} a_{5}$ & - & - & -89.65 & 0.7777 \\
\hline & $\mathrm{a}_{2} \mathrm{a}_{6}$ & - & - & - & -74.85 \\
\hline & $a_{3} a_{3}$ & 554.2 & 138.4 & 540.4 & 579.2 \\
\hline & $a_{3} a_{4}$ & - & 11.88 & -183.5 & -153.7 \\
\hline & $a_{3} a_{5}$ & - & - & 43.21 & -11.79 \\
\hline & $a_{3} a_{6}$ & - & - & - & -61.2 \\
\hline & $a_{4} a_{4}$ & - & 34.62 & 192.3 & 173 \\
\hline & $a_{4} a_{5}$ & - & - & 11.92 & 6.007 \\
\hline & $a_{4} a_{6}$ & - & - & - & 50.33 \\
\hline & $a_{5} a_{5}$ & - & - & 45.43 & 17.54 \\
\hline & $a_{5} a_{6}$ & - & - & - & 1.269 \\
\hline & $a_{6} a_{6}$ & - & - & - & 23.91 \\
\hline \multirow{22}{*}{ Environmental permanent random components } & $\mathrm{p}_{1} \mathrm{p}_{1}$ & $1.50 \mathrm{E}+04$ & $1.55 \mathrm{E}+04$ & $1.50 \mathrm{E}+04$ & $1.52 \mathrm{E}+04$ \\
\hline & $\mathrm{p}_{1} \mathrm{p}_{2}$ & 1,292 & 746.2 & 1,310 & 1,264 \\
\hline & $\mathrm{p}_{1} \mathrm{p}_{3}$ & $-1,002$ & -847.3 & $-1,180$ & $-1,197$ \\
\hline & $\mathrm{p}_{1} \mathrm{p}_{4}$ & - & 37.17 & -56.95 & -26.07 \\
\hline & $\mathrm{p}_{1} \mathrm{p}_{5}$ & - & - & -882.7 & -799.2 \\
\hline & $\mathrm{p}_{1} \mathrm{p}_{6}$ & - & - & - & 59.52 \\
\hline & $\mathrm{p}_{2} \mathrm{p}_{2}$ & 3,964 & 4,478 & 4,176 & 4,178 \\
\hline & $\mathrm{p}_{2} \mathrm{p}_{3}$ & -92.47 & -112.9 & -28.0 & -49.0 \\
\hline & $\mathrm{p}_{2} \mathrm{p}_{4}$ & - & -283.8 & -72.45 & -111 \\
\hline & $\mathrm{p}_{2} \mathrm{p}_{5}$ & - & - & -68.91 & -102.4 \\
\hline & $\mathrm{p}_{2} \mathrm{P}_{6}$ & - & - & - & -181.3 \\
\hline & $\mathrm{p}_{3} \mathrm{p}_{3}$ & 1,909 & 2,314 & 1,847 & 1,886 \\
\hline & $\mathrm{p}_{3} \mathrm{p}_{4}$ & - & -270.5 & -83.54 & -94.2 \\
\hline & $\mathrm{p}_{3} \mathrm{P}_{5}$ & - & - & -570.3 & -453.4 \\
\hline & $\mathrm{p}_{3} \mathrm{P}_{6}$ & - & - & - & -153.6 \\
\hline & $\mathrm{P}_{4} \mathrm{P}_{4}$ & - & 1,077 & 1,023 & 1,002 \\
\hline & $\mathrm{P}_{4} \mathrm{P}_{5}$ & - & - & -226.1 & -139.9 \\
\hline & $\mathrm{p}_{4} \mathrm{P}_{6}$ & - & - & - & -295 \\
\hline & $\mathrm{p}_{5} \mathrm{p}_{5}$ & - & - & 374.8 & 638 \\
\hline & $\mathrm{p}_{5} \mathrm{P}_{6}$ & - & - & - & -160.6 \\
\hline & $\mathrm{p}_{6} \mathrm{P}_{6}$ & - & - & - & 275.4 \\
\hline & $\mathrm{e}$ & $1.47 \mathrm{E}+04$ & $1.40 \mathrm{E}+04$ & $1.36 \mathrm{E}+04$ & $1.33 \mathrm{E}+04$ \\
\hline
\end{tabular}

environmental effects were associated with the first coefficient $\left(\mathrm{a}_{1}\right.$ and $\left.\mathrm{p}_{1}\right)$ for milk, fat, and protein production.

Heritability estimates of milk, fat, and protein production persistence measures ranged from 0.04 to $0.32,0.00$ to 0.23 , and 0.00 to 0.27 , respectively (Table 6), suggesting that these traits have low to moderate heritability, and therefore, their use in genetic selection processes may promote genetic progress.

Those heritability estimates are higher than those found by Jakobsen et al. (2002) in Denmark for five out of the six persistence measures used in the present study. Those authors obtained values from 0.09 to 0.24 , from 0.10 to 0.31 , and from 0.07 to 0.19 , respectively, for milk, fat, and protein production persistence of Holstein cows.

In Brazil, Cobuci et al. (2004) and Dorneles et al. (2009) evaluated similar measures in milk production records of
Holstein cattle reared in the states of Minas Gerais and Rio Grande do Sul, respectively, and found that heritability ranged from 0.05 to 0.27 .

Additionally, the few studies that evaluated fat and protein production persistence, carried out by Cole \& VanRaden (2006) and Strabel \& Jamrozik (2006), along with other persistence measures not included in the present study, determined heritabilities ranging from 0.10 to 0.11 , from 0.07 to 0.12 , and from 0.09 to 0.10 , for milk, fat, and protein production persistence, respectively.

According to Madsen (1975), differences among heritability values may have been caused by three different factors. The first is related to the biological efficiency of the type of persistence measurement (i.e., the production differences among different periods should be considered in absolute or relative terms). The second is associated to 
Table 5 - Genetic and permanent environmental covariance estimated by random regression and residual variance coefficients obtained by fitting test-day protein production in different models

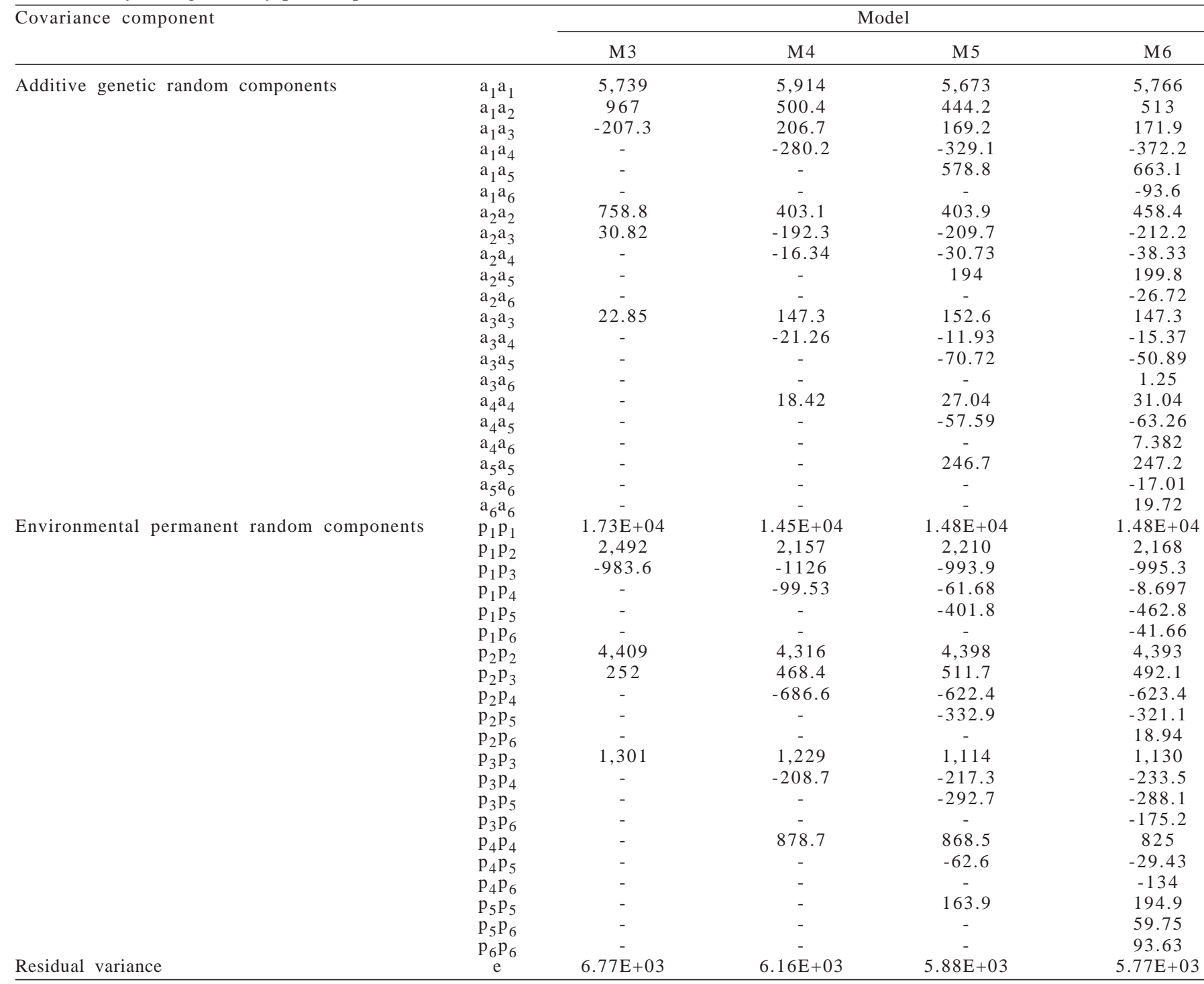

the statistical efficiency of the type of persistence measure, while the third is linked to the lactation period used to calculate the persistence measure.

Moreover, estimated heritabilities depended on the method used to calculate the persistence measure (Table 6). This may partially explain the reason why many attempts were made in the last decade to provide a better estimation of this characteristic by proposing several different persistence measures.

Heritability estimates for total 305-day production ranged from 0.31 to 0.32 for milk production, from 0.30 to 0.33 for fat production, and from 0.25 to 0.29 for protein production (Table 6). As compared to the estimates of persistence measures, there was less variation in heritability among models for total 305-day production.

Based on reports by Madsen (1975), which were previously mentioned, it may be inferred that variance components obtained during the lactation period are used to calculate 305-day yield heritability, and probably this is the reason these estimates are submitted to less variation.

The magnitude of the heritability estimates for total 305-day production is similar to those found by Jakobsen et al. (2002), who determined values of $0.42,0.37$, and 0.36 for milk, fat and protein production, respectively. Moreover, these estimates are higher than the heritability values $(0.18$, 0.12 , and 0.13 ) obtained by Strabel \& Jamrozik (2006), for milk, fat and protein production, respectively.

In Brazil, studies with Holstein cows conducted by Cobuci et al. (2004), Melo et al. (2005), and Dorneles et at. (2009), using milk yield records, estimated heritability values of $0.35,0.27$, and 0.25 for total 305-day milk yield, respectively. It must be noted that, to date, there have been no studies on fat and protein production using random regression models in Brazil. 
In general, persistence heritability values significantly varied among persistence measure types. For some measures, heritability values indicated that a moderate fraction of the total persistence variation is due to additive genetic factors. It is important to observe that, in one sense, the $\mathrm{PS}_{2}$ measure presented the highest heritability values of milk, fat, and protein production persistence.

The efficiency of different measures of milk production persistence was obtained by means of a genetic correlation between persistence and total milk production (in 305 days), assuming the same production level in cows from the same herd (Madsen, 1975).

The estimates of the genetic correlation between persistence measures and total production obtained in the present study ranged from -0.38 to 0.54 , from -0.39 to 0.97 , and from -0.78 to 0.67 for milk, fat, and protein production, respectively (Table 7).

Lower values were found by Jakobsen et al. (2002), who used similar measures and reported genetic correlations ranging from 0.00 to 0.47 for milk, from -0.30 to 0.10 for fat, and from -0.20 to 0.53 , for protein production. However, the magnitude of the genetic correlation between yield and milk yield persistence were similar in magnitude $(-0.31$ to 0.55$)$ to those observed in Brazil by Cobuci et al. (2004) in Holstein cows.

According to Jakobsen et al. (2002), a good persistence measure should have high heritability and low genetic correlation with total yield, because, otherwise, there would be no justification for studies whose objectives were the selection of cows for lactation persistence, according to Cobuci et al. (2003); it would suffice, therefore, to select them for total milk yield, which would consequently improve lactation persistence.

In an attempt to provide a better expression of production persistence, Cole \&VanRaden (2006) proposed a measure that considers yield persistence deviations on the test-day as affected by days in lactation. Those authors obtained low genetic correlation values among total milk yield and milk (0.05), fat (0.12), and protein $(-0.09)$ production persistence in Holstein cows.

In general, the magnitude of the obtained values (Table 7) suggests that not only heritabilities of milk, fat, and protein production persistence measures, but also the estimates of their genetic correlations with total

Table 6 - Heritability estimates of different milk, fat, and protein production persistence and 305-day milk, fat, and protein production obtained by random regression models

\begin{tabular}{|c|c|c|c|c|c|c|c|c|}
\hline Trait & Model & $\mathrm{PS}_{1}$ & $\mathrm{PS}_{2}$ & $\mathrm{PS}_{3}$ & $\mathrm{PS}_{4}$ & $\mathrm{PS}_{5}$ & $\mathrm{PS}_{6}$ & $\mathrm{P}_{305}$ \\
\hline & M3 & 0.12 & 0.31 & 0.27 & 0.14 & 0.05 & 0.08 & 0.32 \\
\hline \multirow[t]{4}{*}{ Milk } & M4 & 0.12 & 0.32 & 0.26 & 0.15 & 0.05 & 0.08 & 0.31 \\
\hline & M5 & 0.14 & 0.31 & 0.27 & 0.16 & 0.05 & 0.10 & 0.31 \\
\hline & M6 & 0.14 & 0.30 & 0.26 & 0.18 & 0.04 & 0.09 & 0.32 \\
\hline & M3 & 0.06 & 0.23 & 0.19 & 0.06 & 0.06 & 0.06 & 0.33 \\
\hline \multirow[t]{4}{*}{ Fat } & M4 & 0.02 & 0.11 & 0.08 & 0.03 & 0.00 & 0.01 & 0.30 \\
\hline & M5 & 0.05 & 0.18 & 0.17 & 0.05 & 0.03 & 0.05 & 0.33 \\
\hline & M6 & 0.07 & 0.20 & 0.17 & 0.07 & 0.04 & 0.05 & 0.32 \\
\hline & M3 & 0.08 & 0.10 & 0.15 & 0.05 & 0.05 & 0.07 & 0.25 \\
\hline \multirow[t]{3}{*}{ Protein } & M4 & 0.03 & 0.17 & 0.08 & 0.05 & 0.01 & 0.02 & 0.29 \\
\hline & M5 & 0.05 & 0.27 & 0.08 & 0.10 & 0.00 & 0.03 & 0.28 \\
\hline & M6 & 0.06 & 0.27 & 0.09 & 0.12 & 0.01 & 0.04 & 0.28 \\
\hline
\end{tabular}

Table 7 - Genetic correlations among milk, fat, and protein yield persistence and milk, fat and protein production in 305 days, obtained by different random regression models

\begin{tabular}{|c|c|c|c|c|c|c|c|}
\hline Trait & Model & $\mathrm{PS}_{1}$ & $\mathrm{PS}_{2}$ & $\mathrm{PS}_{3}$ & $\mathrm{PS}_{4}$ & $\mathrm{PS}_{5}$ & $\mathrm{PS}_{6}$ \\
\hline & M3 & 0.45 & 0.54 & 0.49 & 0.52 & -0.25 & 0.35 \\
\hline \multirow[t]{4}{*}{ Milk } & M4 & 0.44 & 0.53 & 0.48 & 0.50 & -0.25 & 0.36 \\
\hline & M5 & 0.46 & 0.53 & 0.49 & 0.50 & -0.30 & 0.39 \\
\hline & M6 & 0.48 & 0.53 & 0.50 & 0.48 & -0.38 & 0.43 \\
\hline & M3 & 0.29 & 0.41 & 0.36 & 0.41 & -0.07 & 0.16 \\
\hline \multirow[t]{4}{*}{ Fat } & M4 & 0.91 & 0.96 & 0.95 & 0.97 & -0.39 & 0.74 \\
\hline & M5 & 0.34 & 0.48 & 0.35 & 0.51 & -0.01 & 0.23 \\
\hline & M6 & 0.34 & 0.46 & 0.38 & 0.47 & -0.07 & 0.26 \\
\hline & M3 & 0.42 & 0.61 & 0.46 & 0.53 & -0.31 & 0.36 \\
\hline \multirow[t]{3}{*}{ Protein } & M4 & 0.47 & 0.11 & 0.35 & 0.28 & -0.78 & 0.67 \\
\hline & M5 & 0.48 & 0.25 & 0.32 & 0.38 & -0.70 & 0.63 \\
\hline & M6 & 0.52 & 0.29 & 0.35 & 0.44 & -0.63 & 0.64 \\
\hline
\end{tabular}


305-day production depend on the type of measure and model.

However, the results of the criteria used to compare the models indicated that the best fit was obtained by models using Legendre polynomials of higher orders (Table 8). These results are consistent with those of Guo \& Schaeffer (2002), who reported better fit in models including a higher number of parameters.

In Table 8, a reduction of the values of $-2 \log$ maximum likelihood function (ML), Akaiake information criterion and sum of the residual variance in lactation are observed as Legendre polynomial order increases. On the other hand, with the Bayesian information criterion model, fat and protein production values increase between the fifth and the sixth order Legendre polynomial.
Therefore, these results are consistent with those reported by El Faro \&Albuquerque (2003) and Liu et al. (2006), who asserted that the choice of the model with the best quality of fit is not a simple task and the methods employed for this choice may often lead to conflicting results.

It must be noted that random regression models using Legendre polynomials of the fourth or the fifth order are often selected in comparison tests, such as those suited for milk yield records (Guo \& Schaeffer, 2002, Costa et al., 2005; Cobuci et al., 2006; Liu et al., 2006).

Therefore, Legendre polynomial models of fifth and the sixth order with $\mathrm{PS}_{2}$ persistence measure may be good options when making future genetic evaluations of milk, fat, and protein yield persistence in Holstein cows as these models presented the best results for all the three traits.

Table 8 - Values of tests obtained by different random regression models in the analysis of production persistence

\begin{tabular}{|c|c|c|c|c|c|}
\hline Trait & Model & $-2 \log (M L)$ & AIC & BIC & SRV \\
\hline & M3 & $280,401.1050$ & $280,439.1050$ & $280,659.9037$ & 1836.90 \\
\hline \multirow{3}{*}{ Milk } & M4 & $278,321.6277$ & $278,387.6277$ & $278,771.1201$ & 1608.30 \\
\hline & M5 & $277,127.5933$ & $277,229.5933$ & $277,822.2634$ & 1483.20 \\
\hline & M3 & $414,796.1485$ & $414,834.1485$ & $415,050.4125$ & $4398,000.00$ \\
\hline \multirow[t]{2}{*}{ Fat } & M4 & $414,553.9960$ & $414,619.9960$ & $414,995.6124$ & $4200,000.00$ \\
\hline & M5 & $414,311.4392$ & $414,413.4392$ & $414,993.9373$ & $4086,000.00$ \\
\hline \multirow[t]{3}{*}{ Protein } & M4 & $93,628.5643$ & $93,694.5643$ & $94,050.1576$ & $1848,300.00$ \\
\hline & M5 & $93,485.6116$ & $93,587.6116$ & $94,137.1649$ & $1764,000.00$ \\
\hline & M6 & $93,389.4335$ & $93,535.4335$ & $94,322.0489$ & $1732,200.00$ \\
\hline
\end{tabular}

\section{Conclusions}

Estimates of genetic parameters of milk, fat, and protein production persistence are different for each measure and model applied. However, the use of the $\mathrm{PS}_{2}$ measure with Legendre polynomial model of the fifth or sixth order are good options when conducting genetic evaluations of Holstein cows reared in the State of Minas Gerais.

\section{References}

AKAIKE, H. Information theory and an extension of the maximum likelihood principle. In: INTERNATIONAL SYMPOSIUM ON INFORMATION THEORY, 2., 1973, Budapeste. Proceedings... Budapeste, 1973. p.267-281.

COBUCI, J.A.; COSTA, C.N.; TEIXEIRA, N.M. et al. Utilização dos polinômios de Legendre e da função de Wilmink em avaliações genéticas para persistência na lactação de animais da raça Holandesa. Arquivo Brasileiro de Medicina Veterinária e Zootecnia, v.58, n.4, p.614-623, 2006.

COBUCI, J.A.; EUCLYDES, R. F.; COSTA, C.N. et al. Análises da persistência na lactação de vacas da raça holandesa, usando produção no dia do controle e modelo de regressão aleatória. Revista Brasileira de Zootecnia, v.33, n.3, p.546-555, 2004.

COBUCI, J.A.; EUCLYDES, R.F.; PEREIRA, C.S. et al. Persistência na lactação - uma revisão. Archivos Latinoamericanos de Producción Animal, v.11, p.163-173, 2003.

COLE, J.B.; VANRADEN, P.M. Genetic Evaluation and Best Prediction of Lactation Persistency. Journal of Dairy Science, v.89, p.2722-2728, 2006.

COSTA, C.N.; MELO, C.M.R. de; MACHADO, C.H.C. et al. Parâmetros genéticos para a produção de leite de controles individuais de vacas da raça Gir estimados com modelos de repetibilidade e regressão aleatória. Revista Brasileira de Zootecnia, v.34, n.5, p.1519-1530, 2005.

DORNELES, C.K.P.; RORATO, P.R.R.; COBUCI, J.A. et al. Persistência na lactação para vacas da raça Holandesa criadas no Estado do Rio Grande do Sul via modelos de regressão aleatória. Ciência Rural, v.39, n.5, p.1485-1491, 2009. 
EL FARO, L.; ALBUQUERQUE, L.G. Utilização de modelos de regressão aleatória para produção de leite no dia do controle, com diferentes estruturas de variâncias residuais. Revista Brasileira de Zootecnia, v.32, n.5, p.1104-1113, 2003.

GUO, Z.; SCHAEFFER, L.R. Random regression submodel comparison. In: WORLD CONGRESS GENETIC APPLIED LIVESTOCK PRODUCTION, 7., 2002, Montpellier, France. Proceedings... Montpellier, 2002. (CD-ROM).

JAKOBSEN, J.H.; MADSEN, P.; JENSEN, J. et al. Genetic parameters for milk production and persistency for Danish Holstein estimated in random regression models using REML. Journal of Dairy Science, v.85, n.6, p.1607-1616, 2002.

JAMROZIK, J.; KISTEMAKER, G.J.; DEKKERS, J.C.M. et al. Comparison of possible covariates for use in a random regression model for analyses of test day yields. Journal of Dairy Science, v.80, n.10, p.2550-2556, 1997.

LIN, C.Y.; TOGASHI, K. Simultaneous improvement of lactation milk and persistency. In: WORLD CONGRESS GENETIC APPLIED LIVESTOCK PRODUCTION, 7., 2002, Montpellier, France. Proceedings... Montpellier, 2002. (CD-ROM).

LIU, Y.X.; ZHANG, J.; SCHAEFFER L.R. et al. Short communication: Optimal random regression models for milk production in diary cattle. Journal of Dairy Science, v.89, p.2233-2235, 2006.

MISZTAL, REMLF90 Manual: Disponível em: <http://nce.ads.uga.edu/ $\sim$ ignacy/numpub/blupf90/docs/remlf90.pdf $>2002$. Acesso em: 3/3/2008.

MADSEN, O. A comparison of some suggested measures of persistency of milk yield in dairy cows. Animal Production, v.20, p.191-197, 1975.

MELO, C.M.R.; PACKER, I.U.; COSTA, C.N. et al. Parâmetros genéticos para as produções de leite no dia do controle e da primeira lactação de vacas da raça Holandesa. Revista Brasileira de Zootecnia, v.34, n.3, p.796-806, 2005.

SCHWARZ, G. Estimating the dimension of a model. The Annals of Statistics, v.6, n.2, p.461-464, 1978.

STRABEL, T.; JAMROZIK, J. Genetic analysis of milk production traits of Polish Black and White cattle using large-scale random regression test-day models. Journal of Dairy Science, v.89, p.3152-3163, 2006.

TEKERLI, M.; AKINCI, Z.; DOGAN, I. et al. Factors affecting the shape of lactation curves of Holstein cows from the Balikesir province of Tukey. Journal of Dairy Science, v.83, n.6, p.1381-1386, 2000.

WOOD, P.D.P. Algebric model of lactation curve in cattle. Nature, v.216, n.5111, p.164-165, 1967. 